\title{
FOUR NEW SPECIES OF SECAMONE (APOCYNACEAE, SECAMONOIDEAE) FROM INDONESIA
}

\author{
JENS KLACKENBERG \\ Naturhistoriska riksmuseet, Sektionen för fanerogambotanik, \\ Box 50007, SE-10405 Stockholm, Sweden; e-mail: klack@nrm.se
}

\section{SUMMARY}

Four new species of Secamone (Apocynaceae, Secamonoideae) from the Sulawesi archipelago in Indonesia, viz. S. axillaris Klack., S. kjellbergii Klack. and S. variicolor Klack. from Sulawesi itself, and S. celebica Klack. from adjacent Salajar Island, are described, illustrated and compared with related taxa.

Key words: Secamone, Toxocarpus, Apocynaceae, Indonesia, new species.

\section{INTRODUCTION}

During a worldwide revision of the subfamily Secamonoideae (Apocynaceae) I came across some specimens from the Sulawesi archipelago that do not fit into any known taxon and must be described as four new species of Secamone R.Br. The genus Secamone is placed in subfamily Secamonoideae of Apocynaceae. This subfamily is characterized by having four pollinia in each pollinarium, not two as in subfamily Asclepiadoideae, neither a spate-like translator as in Periplocoideae, two to Secamonoideae phylogenetically closely related taxa (see Endress \& Bruyns (2000) for a classification of Apocynaceae with Asclepiadaceae included). Secamone is a palaeotropic genus of suffrutescent twiners or small scrambling herbs, rarely erect shrubs, with usually small white to yellow flowers. It is distributed in tropical and southern Africa as well as in Madagascar and on several smaller islands in the Indian Ocean. In Asia it is found in Sri Lanka and southern India to the Himalayas, and from southern China in the northwest through SE Asia to eastern Australia and New Caledonia (Goyder, 1992; Klackenberg, 1992a, b, 2001).

The four species here described have staminal coronas with an outer and an inner lobe, elongated style-head as well as colleters at the very base of the leaf lamina above. These characters would place them in the genus Toxocarpus Wight \& Arn., one of the genera of Secamonoideae that usually have been accepted in SE Asia. However, Toxocarpus and Secamone are considered to be congeneric (for a discussion see Klackenberg, 2004), and the new taxa are described in Secamone. Accepted taxa of Toxocarpus will succesfully be transferred to Secamone during the ongoing revision. In this article taxa with these characters will be called toxocarpoid Secamone. The horny guiding structure for the pollinia along the stamens (i.e. the anther wings) are short in the four new species. This conforms with observations from other toxocarpoid Secamone. The four pollinia are glued together and adhere to a soft minute corpusculum by a short stipe. Also the 
gynoecium conforms to Secamonoideae in general. The ovary consists of two separate subinferior carpels that are united at the base only, each with numerous ovules, and without a distinct style.

Two genera of Secamonoideae in Asia, Secamone s.str. (two species) and Genianthus Hook.f. (15 species) have recently been revised (Klackenberg, 1992a, 1995). However, a modern revision of the toxocarpoid Secamone, the largest group of this subfamily in the area with more than 60 species described in Asia, is lacking, the latest treatment being that of Tsiang in 1939. Tsiang recognized 41 species of toxocarpoid Secamone in Asia, but hampered by the war to complete his intended revision, he presented in his paper only 20 species of which six come from the SE Asian archipelago. Furthermore, only few specimens from this area are present in herbaria and several taxa are still based on only one or two collections. Consequently, Secamonoideae are still poorly known in Indonesia.

No endemic species of Secamonoideae are up to now known from Sulawesi. Two species with rather wide distribution, however, are known from this island, viz. Genianthus ellipticus (Blume) Bakh.f. which has been collected also in Java, Borneo and the Philippines (Klackenberg, 1995), and Secamone elliptica R.Br. which is known from most of SE Asia (S China to N Australia and New Caledonia) (Klackenberg, 1992a). Both these species differ from the new taxa described here by their small flowers (G. ellipticus furthermore by its hairy corolla lobes) and by the structure of their gynostegia: G. ellipticus has a broad and short style-head and S. elliptica a short style-head and falcate corona lobes (Klackenberg, 1992a, f. 3; 1995, f. 18). The four new species, except for $S$. axillaris (see below), formerly have been filed in herbaria under unidentified Toxocarpus.

The new Sulawesi species are easily distinguished from each other. Secamone variicolor is characterized by its inflorescences with bright yellow and dark red flowers, the other species having uniformly yellow or greenish yellow flowers. It furthermore differs by its long and thin but also deeply bifid style-head, cleft almost half-way to the base, and by its mouth of the corolla tube that is covered by conspicuous flat white hairs when dry. Two of the other species are furnished with ordinary cylindric hairs and one, S. axillaris, is completely glabrous. Secamone axillaris differs from other Asian toxocarpoid Secamone by having inflorescences that adhere to the stem in an axillary position, i.e. directly above the subtending leaves. The predominant position in Secamonoideae and Asclepiadoideae is extra-axillary, i.e. the cyme is situated just beside a petiole, not in the axil nor in the middle between the opposite petiole bases. Some Malagasy and African Secamone, however, have also axillary inflorescences (Klackenberg, 1992b, 1998, 2000, 2001, 2003). Furthermore, S. axillaris has a totally glabrous corolla, the other species known from Sulawesi have at least the tube hairy inside. Secamone celebica, which is similar to $S$. axillaris in flower morphology with its long and narrow but entire style-head and lanceolate to narrowly elliptic leaves, differs in addition to having extra-axillary inflorescences and hairy corolla tubes inside, also by shorter calyx lobes and bracts. Secamone kjellbergii differs by its thick distinctly club-shaped upper portion of the style-head, the other species being furnished with cylindric to very narrowly conical style-heads.

There are also some species on islands adjacent to Sulawesi that are of interest. Both in habit and in flower structure Toxocarpus glaucus Decne. and T. gracilis Decne. 
from the Philippines are similar to $S$. kjellbergii and S. celebica but differ by having glabrous corolla tubes. Secamone axillaris, which has a glabrous corolla tube, differs by its axillary inflorescences. Furthermore, S. kjellbergii and S. celebica are similar to T. loheri Schltr. from the Philippines. Secamone celebica, however, differs by the more deeply cleft corolla lobes, the entire and narrowly conical style-head as well as the acute corona lobes. Furthermore, the leaves are cordate at the very base (truncate to cuneate in T. loheri), equally pale on both sides when dry (vs distinctly darker above), distinctly acuminate (vs acute) and have different venation. Secamone kjellbergii differs by its clavate upper part of style-head and by its truncate outer corona lobe.

Another taxon in the area, Toxocarpus merrillii Schltr. from the Philippines, differs from the four new species by having simple corona lobes, as well as broadly elliptic to almost rounded distinctly hairy leaves and large inflorescences. Secamone auriculatus Blume (with S. insularis Miq. included) from Java and Sumatra differs from all four new species by its broad leaves which are subauriculate-cordate at the base and by having a short style-head. Also T. longipetalus Merr. from Borneo differs by its broad and subauriculate-cordate leaves, and furthermore by its lax, diffuse inflorescence with delicate peduncles and pedicels. Very thin branches and delicate inflorescences are also characteristic for $S$. lineata Blume from Java. The type sheet of $S$. axillaris was formerly identified by Hatusima as T. rubricaulis Elmer. The type from the Philippines of T. rubricaulis lacks flowers. However, judging from the venation and the pubescence of the leaves this taxon is a Genianthus rectinervis (Schltr.) Tsiang or G. ellipticus. Toxocarpus elmeri Merr. from Borneo and S. urdanetensis Elmer ex Tsiang from the Philippines have single truncate corona lobes with the free part of the inner lobe lacking, i.e. differently shaped compared to the four new species here described, all of which are furnished with distinct inner lobes. In addition, $S$. urdanetensis differs by its short style-head, which is not protruding from the staminal column. Toxocarpus rhopalophorus Backer from Java differs from all four species by its long, cylindric tube.

\section{TAXONOMY}

\section{Secamone axillaris Klack., spec. nov. - Fig. 1; Map 1}

Species haec inflorescentiis e foliorum axillis ortis, corollis omnino glabris, necnon foliis et calycis lobis et inflorescentiae bracteis longis vel angustis dignoscenda. - Typus: Kjellberg 764 (holo S; iso BO, S), Indonesia, Sulawesi, Kendari, 50 m alt., 8 March 1929.

Suffrutescent twiner; younger branches sparsely reddish hairy. Leaves somewhat coriaceous; blade $10-12.5$ by $2-2.5 \mathrm{~cm}$, narrowly ovate, rounded to truncate at base, acute to somewhat acuminate at apex, glabrous, with 5-10 \pm confluent colleters at the very base above; venation pinnate, looped, secondary veins faintly reticulate below when dry; midrib raised above when dry, midrib and veins raised below, diverging at $70-90^{\circ}$ from the mid-nerve; epidermis smooth on both sides; petiole 5-10 mm long, reddish hairy when young, glabrescent. Inflorescences axillary, shorter to longer than the adjacent leaves but distinctly shorter than mature leaves, 3-7 cm long; cymes rather lax, many-flowered, irregularly mono- to dichasially branched with longer and shorter axes alternating, with reddish hairs; axes much varying, very short to usually $5-10 \mathrm{~mm}$ 


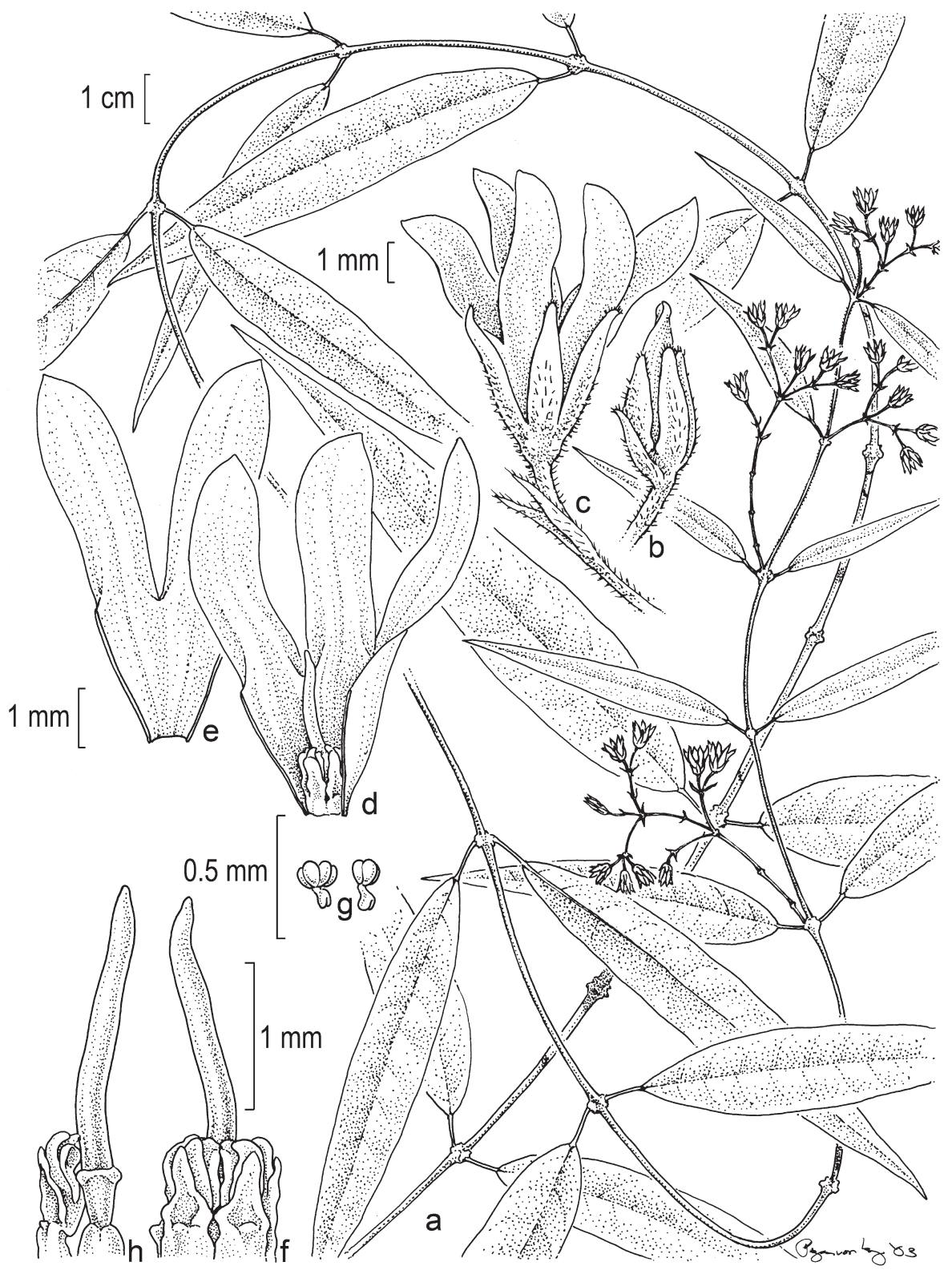

Fig. 1. Secamone axillaris Klack. a. Habit; b. flower in bud; c. flower at anthesis; d. flower with calyx and two corolla lobes removed; e. portion of corolla from within; f. gynostegium; g. pollinia; h. part of ovary, style-head and one stamen (all Kjellberg 769). - Drawn by Pollyanna von Knorring, Stockholm. 
long, longest ones up to $25 \mathrm{~mm}$; pedicels $2-7 \mathrm{~mm}$ long; bracts $2-2.5 \mathrm{~mm}$ long, narrowly triangular to linear. Calyx lobes much longer than the corolla tube, 3.4 by $0.9-1.1 \mathrm{~mm}$, narrowly ovate, acute but rounded at the very apex, with rather sparse and long reddish hairs outside and along the margins, glabrous inside. Corolla narrowly ovoid in bud, contorted with the left lobe margin overlying and with the lobes fused at base for c. 1/3 of their length into a tube, slightly twisted to the right, glabrous on both sides, yellowish green; tube cylindric, 2-2.3 mm long; lobes probably bent outwards, 4-4.4 by c. $1.3 \mathrm{~mm}$, oblong, obliquely acute at the apex. Staminal column $0.7-0.8 \mathrm{~mm}$ high. Corona lobes double; outer part with flat back and dorsiventrally compressed marginal parts, triangular and somewhat hastate, acute at apex, erect, about as long as thecae; inner part dorsiventrally compressed and convex, narrower and slightly longer than the outer lobe. Anther wings shorter than the thecae, c. $0.2 \mathrm{~mm}$ long. Pollinia c. $0.1 \mathrm{~mm}$ long, ellipsoidal. Ovary glabrous. Style-head about three times longer than the staminal column, about as long as the corolla tube; apical portion c. 6 times as long as the basal portion, $2.1 \mathrm{~mm}$ long, entire at the apex, cylindric. Fruits not seen.

Distribution - Sulawesi, known only from the type.

Habit \& Ecology - In rain forest at $50 \mathrm{~m}$ altitude. Flowering in March.

Notes - This species is distinguished by its axillary inflorescences, and also by its narrow leaves, calyx lobes and bracts.

The name alludes to the axillary inflorescences.

\section{Secamone celebica Klack., spec. nov. - Fig. 2; Map 1}

Species haec Toxocarpo glauco Decne. et $T$. gracili Decne. aliquantum similis sed differt corollae tubis pubescentibus et foliis in utrinque paginis in sicco isdem pallidis. - Typus: Docters van Leeuwen 1938 (holo U; iso BO), Indonesia, Zuid Saleyer (Salajar Island), 1913.

Suffrutescent twiner; younger branches covered with reddish retrorse hairs. Leaves somewhat coriaceous; blade $8-12$ by $3-4 \mathrm{~cm}$, narrowly ovate to elliptic, rounded but slightly cordate at the very base, acuminate at apex, glabrous and \pm shining above when dry, with very sparse reddish appressed hairs below, with 5-10 colleters at the very base above; venation pinnate, looped, secondary veins faintly reticulate below when dry; midrib distinctly impressed above when dry, midrib and veins raised below, diverging at $45-60^{\circ}$ from the mid-nerve; epidermis smooth on both sides; petiole $10-15 \mathrm{~mm}$ long, with reddish hairs. Inflorescences extra-axillary, much shorter than the adjacent leaves, 3-4 cm long; cymes rather lax, many-flowered, irregularly mono- to dichasially branched, forked at base, with reddish hairs; axes 1-13 mm long; pedicels 1-3 $\mathrm{mm}$ long; bracts 1-1.5 mm long, triangular. Calyx lobes longer than the corolla tube, $1.6-2$ by $0.9-1.1 \mathrm{~mm}$, ovate, rounded at the apex, more or less covered with reddish hairs outside, glabrous inside. Corolla narrowly ovoid in bud, contorted with the left lobe margin overlying and with the lobes fused at the base for c. 1/4 of their length into a tube, slightly twisted to the right, glabrous outside, hairy inside of the tube and at the base of each lobe, yellow; tube slightly widening towards the mouth and with small pouches below the lobes, c. $1.6 \mathrm{~mm}$ long; lobes slightly curved, c. 4.7 by 1.3 $\mathrm{mm}$, oblong, obtuse at the apex. Staminal column c. $1 \mathrm{~mm}$ high. Corona lobes double; outer part with flat back and dorsiventrally compressed marginal parts, angular-ovate 


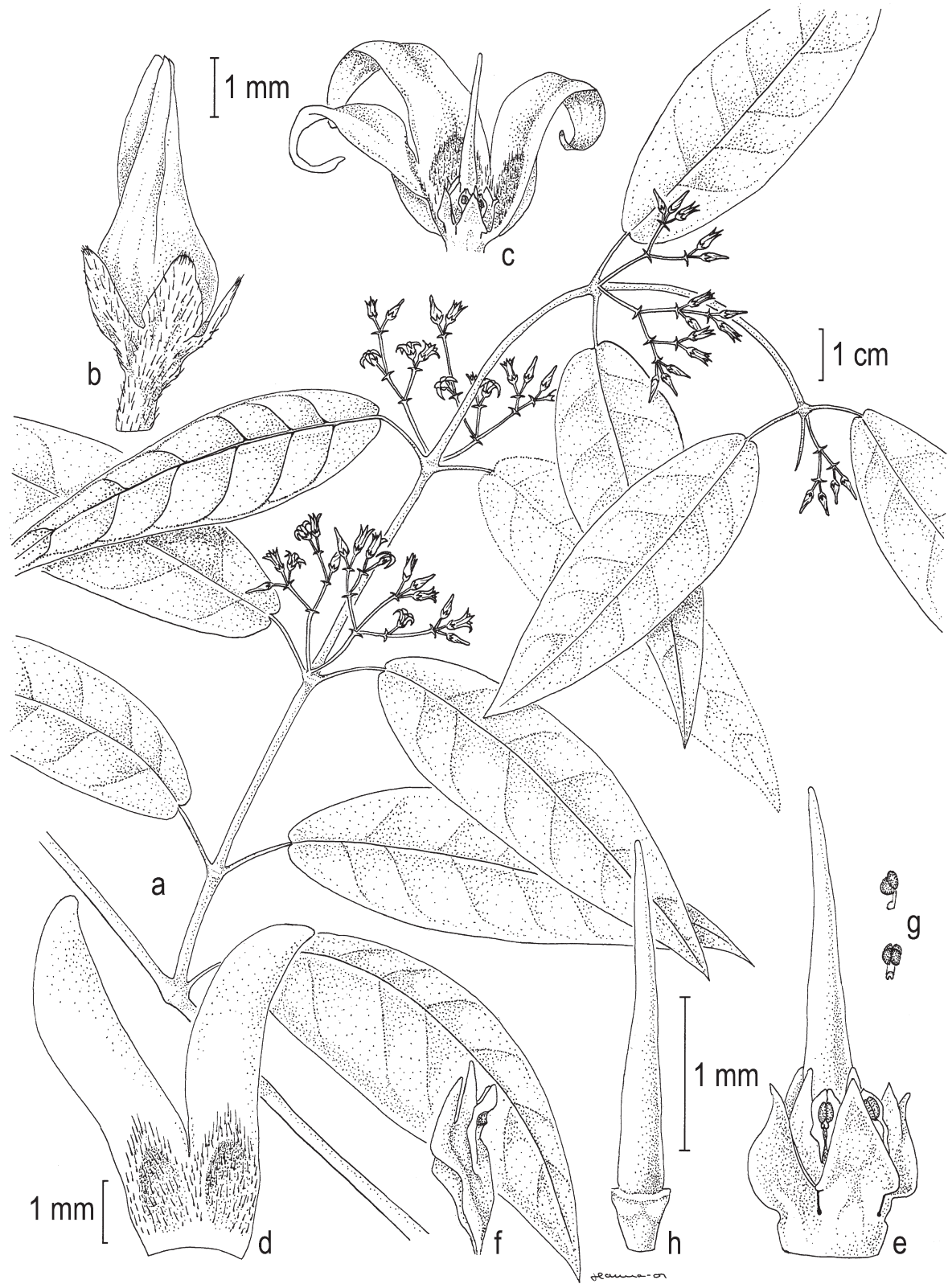

Fig. 2. Secamone celebica Klack. a. Habit; b. flower in bud; c. flower with calyx and two corolla lobes removed; d. portion of corolla from within; e. gynostegium; f. anther, lateral view; g. pollinia; h. style-head (all Docters van Leeuwen 1938). - Drawn by Hanna Lindskog, Stockholm. 


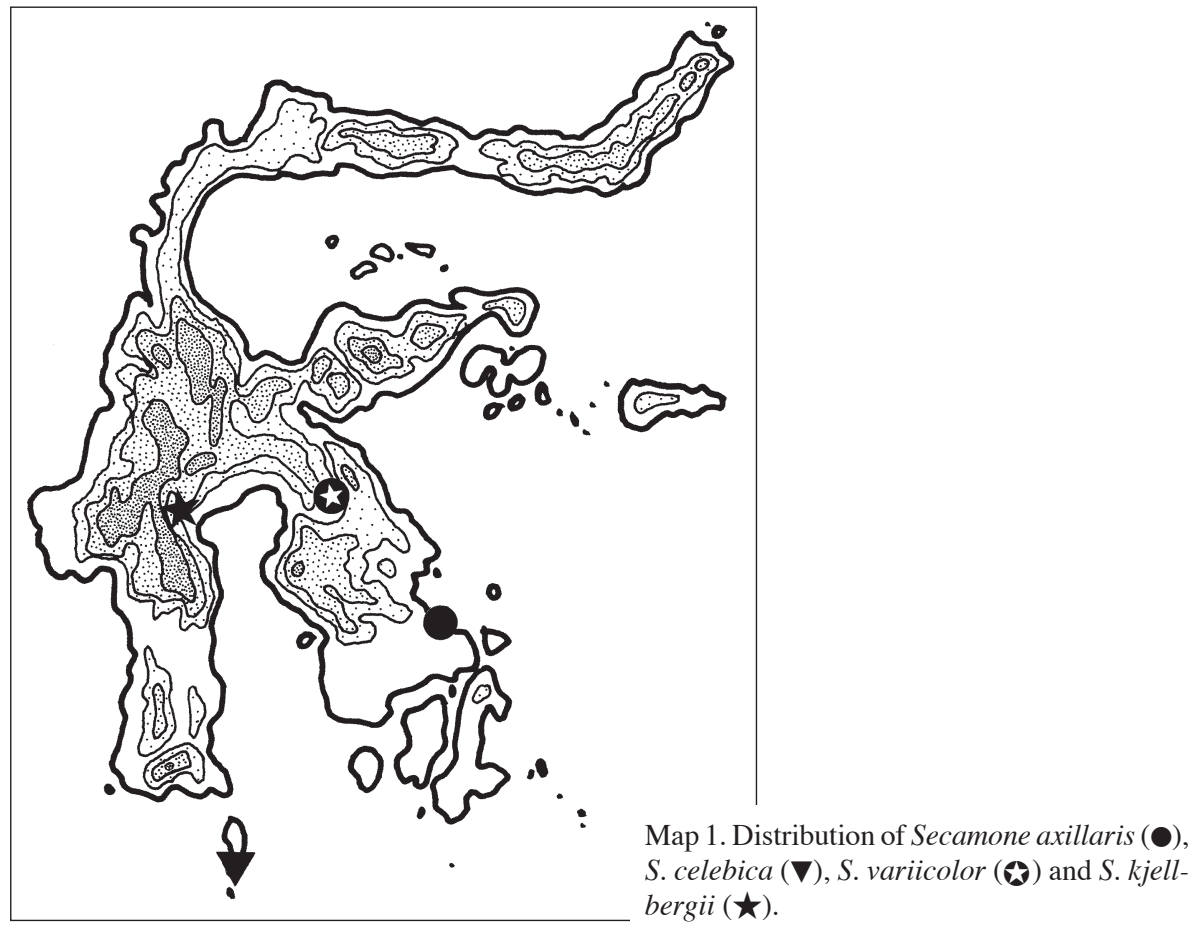

and somewhat hastate, subacute at apex, erect, projecting above the thecae; inner part dorsiventrally compressed, narrow, slightly longer than the outer lobe. Anther wings about as long as thecae, c. $0.2 \mathrm{~mm}$ long. Pollinia c. $0.1 \mathrm{~mm}$ long, ellipsoidal. Ovary glabrous. Style-head about 2.5 times longer than the staminal column, distinctly exserted from the corolla tube; apical portion 4-5 times as long as the basal portion, 2.2 $\mathrm{mm}$ long, entire to slightly bifid at the very apex, cylindric to very narrowly conical. Fruits not seen.

Distribution - Salajar Island in the southern part of the Sulawesi group, known only from the type.

Habit \& Ecology - On rock by the sea. Flowering in May.

Note - This species is distinguished by its entire, narrowly conical style-head, acute corona lobes and equally pale upper and lower sides of the leaves when dry.

\section{Secamone variicolor Klack., spec. nov. - Fig. 3; Map 1}

Species haec colore florum in eadem inflorescentia variabili cum corollis et flavis et rubris praesentibus, stylo longo supra columnam staminalem procurrenti necnon profunde bifido, et corollae ore tubi cum pilis complanatis dignoscenda. - Typus: De Vogel 6126 (holo L; iso BO, KYO), Indonesia, Sulawesi, N shore of Lake Matano, Bonemaitu, E of Nuha, $2^{\circ} 20^{\prime} \mathrm{S}, 121^{\circ} 27^{\prime} \mathrm{E}, 400 \mathrm{~m}$ alt., 5 July 1979.

Suffrutescent twiner; branches covered with reddish hairs particularly on and near the nodes, glabrescent. Leaves somewhat coriaceous; blade $9-12$ by $4-6 \mathrm{~cm}$, elliptic to obovate, cuneate at base, rather abruptly acuminate at apex, with reddish hairs below, 


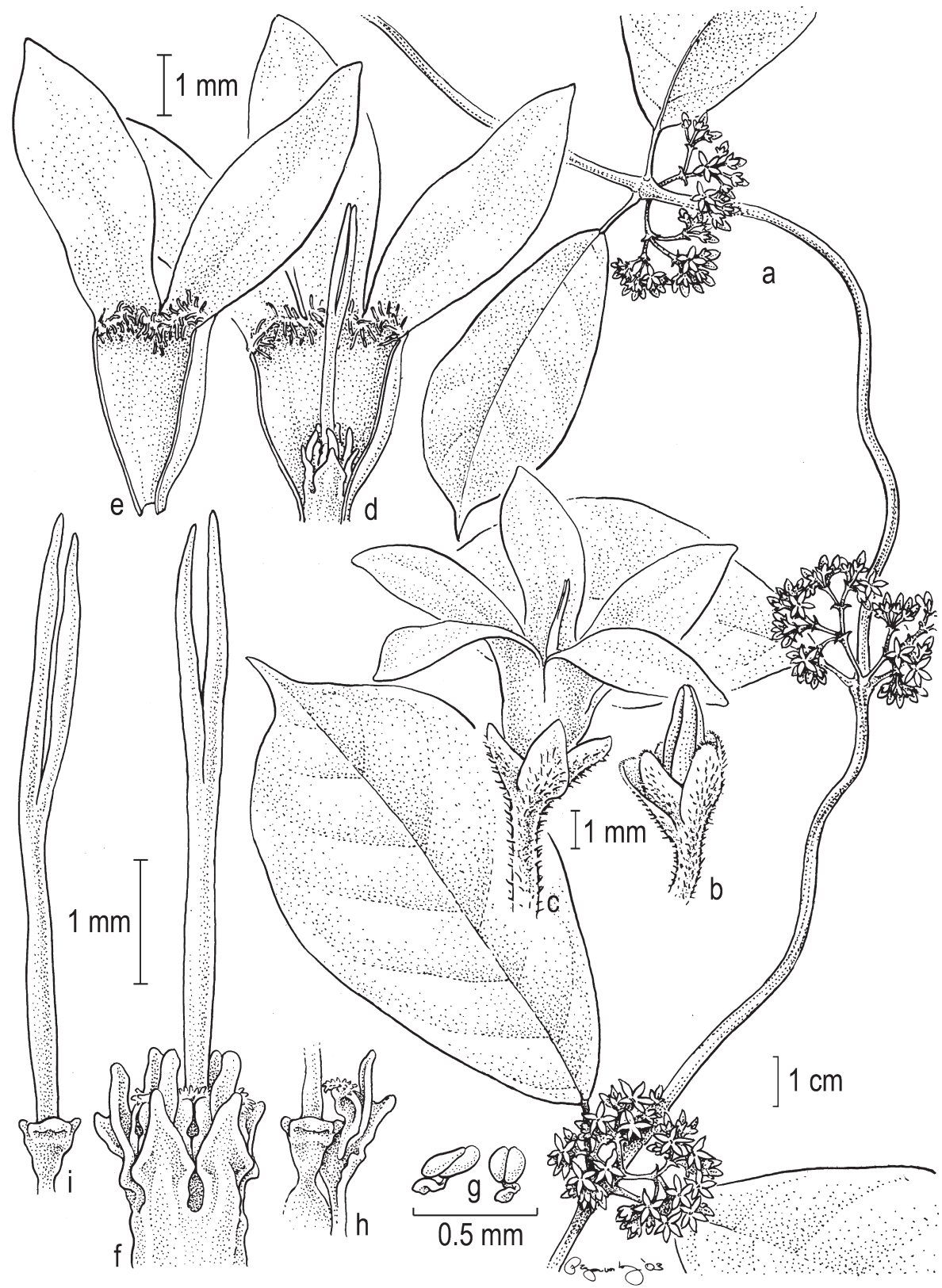

Fig. 3. Secamone variicolor Klack. a. Habit; b. flower in bud; c. flower at anthesis; d. flower with calyx and two corolla lobes removed; e. portion of corolla from within; f. gynostegium; g. pollinia; h. part of ovary, basal part of style-head and one stamen; i. style-head (all De Vogel 6126). - Drawn by Pollyanna von Knorring, Stockholm. 
very sparsely hairy above, with 5-10 colleters at the very base above; venation pinnate, looped, secondary veins faintly reticulate below when dry; midrib impressed at lower half above when dry, midrib and veins raised below, diverging at c. $45^{\circ}$ from the mid-nerve; epidermis smooth on both sides; petiole 10-20 mm long, with reddish hairs. Inflorescences extra-axillary, much shorter than the adjacent leaves, $2-3 \mathrm{~cm}$ long; cymes rather dense, many-flowered, irregularly mono- to dichasially branched, with reddish hairs; axes up to c. $8 \mathrm{~mm}$ long; pedicels $2-4 \mathrm{~mm}$ long; bracts $1-1.5 \mathrm{~mm}$ long, triangular. Calyx lobes shorter than the corolla tube, c. 2.2 by $1.3 \mathrm{~mm}$, ovate, rounded at the apex, densely covered with reddish hairs outside, glabrous inside. Corolla narrowly ovoid in bud, contorted with the left lobe margin overlying and with the lobes fused at the base for c. 1/3 of their length into a tube, not twisted to slightly twisted to the right, glabrous outside, hairy inside at the mouth of the tube particularly along V-formed coralline coronas in the lobe sinuses, bright yellow to dull dark red; tube cylindric, c. $2.9 \mathrm{~mm}$ long; lobes probably rotate, c. 5.7 by $2.4 \mathrm{~mm}$, ovate, subacute at the apex. Staminal column c. $0.9 \mathrm{~mm}$ high (c. $1.2 \mathrm{~mm}$ high with corona lobes included). Corona lobes double; outer part with flat back and dorsiventrally compressed (and reflexed (probably artefact when drying)) marginal parts, triangular, acute at apex, erect, about as long as thecae; inner part dorsiventrally compressed, narrower and longer than the outer lobe, protruding above the thecae. Anther wings about as long as thecae, c. $0.3 \mathrm{~mm}$ long. Pollinia glued together with one pair displaced a little above the other, c. $0.2 \mathrm{~mm}$ long, ellipsoid. Ovary glabrous. Style-head about four times longer than the staminal column, distinctly exserted from the corolla tube; apical portion about 10 times as long as the basal portion, c. $4.8 \mathrm{~mm}$ long, cylindric, distinctly bifid at the apex. Fruits not seen.

Distribution - Sulawesi, known only from the type.

Habit \& Ecology - In somewhat disturbed primary forest at $400 \mathrm{~m}$ altitude in deep hard red clayey soil. Flowering in July.

Notes - This species is distinguished from all known Secamone/Toxocarpus species in the SE Asian archipelago by having both bright yellow and dull dark red flowers present in the same inflorescence. It is furthermore characterized by its large and flat hairs at the mouth of the corolla tube, and by the very long and narrow as well as deeply bifid style-head.

The name alludes to the flowers changing colours.

\section{Secamone kjellbergii Klack., spec. nov. - Fig. 4; Map 1}

Species haec Toxocarpo glauco Decne. et T. gracili Decne. aliquantum similis sed differt corollae tubis pubescentibus et stylo distincte clavato, et coronae lobis exterioribus truncatis. - Typus: Kjellberg 2920 (S), Indonesia, Sulawesi, Rantepao, 600 m alt., 1929.

Suffrutescent twiner; younger branches covered with reddish erect hairs. Leaves herbaceous; blade 7-9 by $3-4 \mathrm{~cm}$, elliptic, cuneate to truncate at base, acuminate at apex, hairy on both sides when young, sparsely hairy below also when older particularly along mid-nerve, glabrescent above, with only 2 or 3 colleters at the very base above; venation pinnate, looped, secondary veins faintly reticulate below when dry; midrib mostly \pm even with lamina but slightly impressed at lower part above when dry, midrib and veins raised below, diverging at $45-60^{\circ}$ from the mid-nerve; epidermis smooth on 


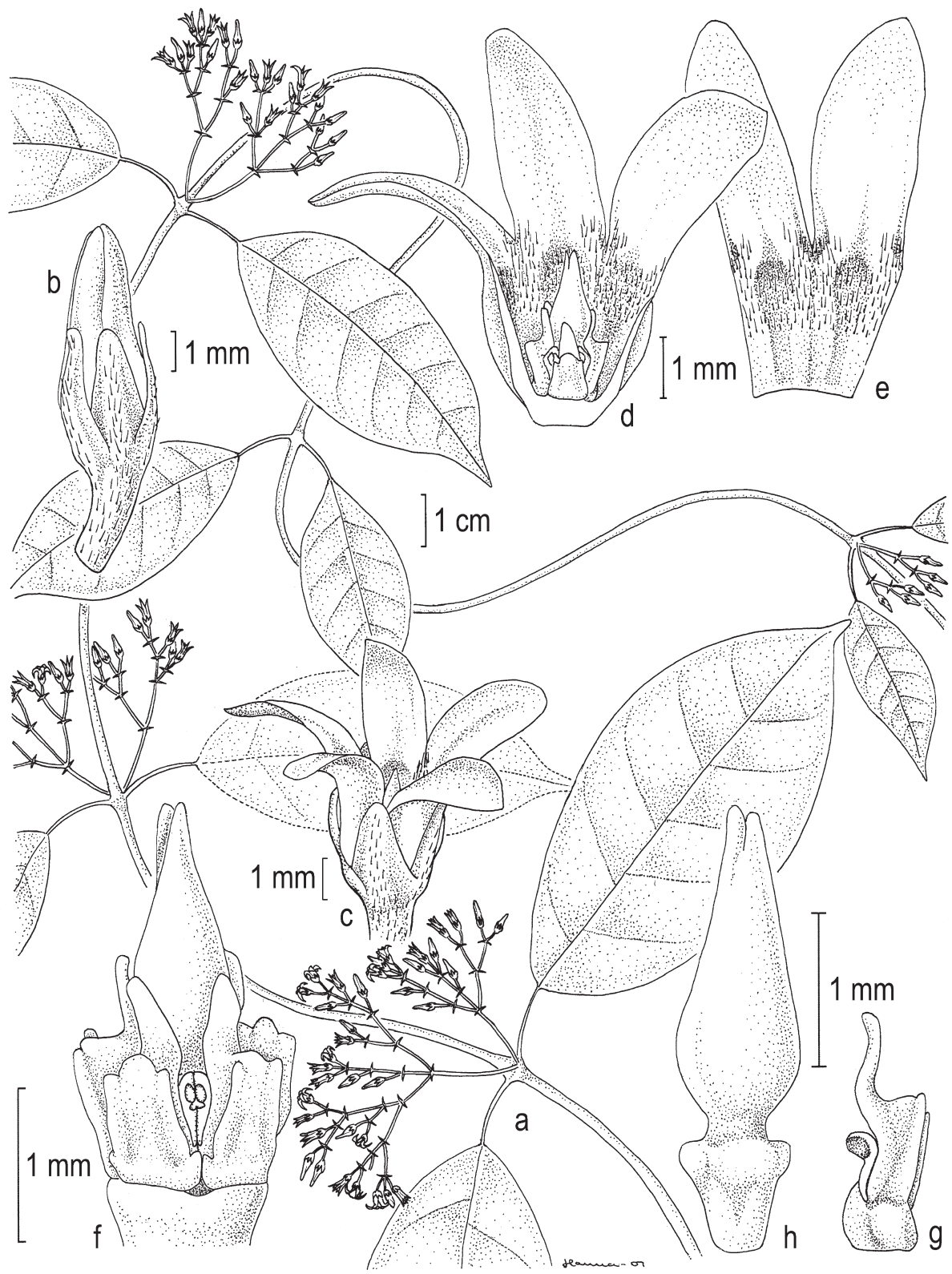

Fig. 4. Secamone kjellbergii Klack. a. Habit; b. flower in bud; c. flower at anthesis; d. flower with calyx and two corolla lobes removed; e. portion of corolla from within; f. gynostegium; g. anther, lateral view; h. style-head (all Kjellberg 2920, b-h from alcohol material). - Drawn by Hanna Lindskog, Stockholm. 
both sides; petiole 10-15 mm long, with reddish hairs. Inflorescences extra-axillary, shorter than the adjacent leaves, 3-4 cm long; cymes rather lax, many-flowered, irregularly mono- to dichasially branched, forked at base, with reddish hairs; axes 1-15 mm long; pedicels 1-4 mm long; bracts 2-3 mm long, narrowly triangular. Calyx lobes longer than the corolla tube, c. 3.7 by $1.7 \mathrm{~mm}$, ovate, rounded at the apex, more or less covered with reddish hairs outside, glabrous inside. Corolla narrowly ovoid in bud, contorted with the left lobe margin overlying and with the lobes fused at the base for c. 1/3 of their length into a tube, not twisted or slightly twisted to the right, glabrous outside, hairy inside of tube and with tufts of slightly longer hairs in the sinuses at the mouth, yellow; tube cylindric and with small pouches below the lobes, c. $2.4 \mathrm{~mm}$ long; lobes straight and bent outwards, c. 4.4 by $1.8 \mathrm{~mm}$, oblong, subacute to obtuse at the apex. Staminal column c. $1.5 \mathrm{~mm}$ high. Corona lobes double; outer part with flat back and dorsiventrally compressed marginal parts, \pm rectangular, truncate with crenate margin at apex, erect, projecting above the thecae; inner part dorsiventrally compressed, much narrower, distinctly longer than the outer lobe. Anther wings about as long as thecae, c. $0.25 \mathrm{~mm}$ long. Pollinia c. $0.15-0.2 \mathrm{~mm}$ long, ellipsoid. Ovary glabrous. Style-head about two times longer than the staminal column, about as long as the corolla tube; apical portion c. 4 times as long as the basal portion, $2.1 \mathrm{~mm}$ long, slightly bifid at the very apex, fusiform. Fruits not seen.

Distribution - Sulawesi, known only from the type.

Habit \& Ecology - Limestone rocks at $600 \mathrm{~m}$ altitude. Flowering in December.

Notes - This species is easily distinguished by its distinctly clavate upper part of the style-head and by the truncate outer corona lobe.

The species epithet honours the Swedish botanist G. Kjellberg, who contributed to the exploration of Sulawesi in 1929 with a substantial collection of herbarium specimens and pickled material.

\section{REFERENCES}

Endress, M.E. \& P.V. Bruyns 2000. A revised classification of the Apocynaceae s.1. Bot. Rev. 66: $1-56$.

Goyder, D. 1992. Secamone (Asclepiadaceae subfam. Secamonoideae) in Africa. Kew Bull. 47: 437-474.

Klackenberg, J. 1992a. Taxonomy of Secamone (Asclepiadaceae) in Asia and Australia. Kew Bull. 47: 595-612.

Klackenberg, J. 1992b. Taxonomy of Secamone s.lat. (Asclepiadaceae) in the Madagascar Region. Opera Bot. 112: 1-127.

Klackenberg, J. 1995. Taxonomy and phylogeny of the SE Asian genus Genianthus (Asclepiadaceae). Bot. Jahrb. Syst. 117: 401-467.

Klackenberg, J. 1998. Secamone drepanoloba, a new species of Asclepiadaceae. Bot. Jahrb. Syst. 120: $119-122$.

Klackenberg, J. 2000. Two new species of Secamone (Apocynaceae, Secamoneae) from Madagascar. Novon 10: 215-219.

Klackenberg, J. 2001. Notes on Secamonoideae (Apocynaceae) in Africa. Adansonia ser. 3, 23: 317-335.

Klackenberg, J. 2003. Secamone galinae (Apocynaceae), a new species from Madagascar. Bot. Jahrb. Syst. 124: 421-425.

Klackenberg, J. 2004. A new species of Secamone (Apocynaceae, Secamonoideae) from Borneo. Blumea 49: 129-133.

Tsiang, Y. 1939. Notes on the Asiatic Apocynales IV. Sunyatsenia 4: 31-94. 